\title{
IS ORGANIC FOOD A SUSTAINABLE CHOICE? EVALUATING ORGANIC FOOD PRODUCTION IN THE FRAMEWORK OF ENVIRONMENTAL SUSTAINABILITY
}

Şirin Gizem KÖSE ${ }^{1}$

\section{ABSTRACT}

Keywords:

Organic Foods,

Sustainable Consumption,

Environmental Sustainability

JEL Codes:

M10, M30, M31

\author{
Received Date (Başvuru Tarihi): \\ Accepted Date (Kabul Tarihi): \\ Published Date (Yayın Tarihi):
}

$28 / 07 / 2020$

$28 / 09 / 2020$
$10 / 12 / 2020$

\section{ORGANİK GIDA SÜRDÜRÜLEBILIIR BİR SEÇİM MIDIIR? ORGANİK GIDA ÜRETIMINI ÇEVRESEL SÜRDÜRÜLEBİLIRLİK ÇERÇEVESINDE DEĞERLENDİRMEK}

$\ddot{O Z Z}$

\section{Anahtar Kelimeler: \\ Organik Gıdalar,}

Sürdürülebilir Tüketim,

Çeoresel Sürdürülebilirlik

JEL Kodlar:

M10, M30, M31
Excessive consumption, deterioration of nature, and misusing the resources are problems of current humanity and future generations. Sustainability has started to become a priority for both practitioners and customers. In this respect, sustainable consumption and production practices stand out in almost all areas. Environmental sustainability concerns also affect food consumption habits. Sustainable agriculture and organic movement accelerated in recent times. In this context, the purpose of this study is to evaluate organic food in the framework of environmental sustainability by investigating literature and consumers' opinions. It is aimed to investigate organic food in terms of environmental sustainability with consumer perspective in this study. This study collected data through InDepth interview method in line with this purpose. The results of the study signify that sustainable consumption and organic food purchase intention are interrelated. It's proposed that environmental sensitivity and environmental knowledge have positive roles, whereas scepticism has a negative role in organic food purchase intention.

\section{DEGERLENDIRMEK}

Aşır tüketim, doğanın tahribi ve kaynakların kötü kullanımı hem günümüz insanliğının hem de gelecek nesillerin problemleridir. Sürdürülebilirlik hem uygulamacılarn hem de tüketicilerin önceliği olmaya başlamıştır. Bu doğrultuda sürdürülebilir tüketim ve üretim uygulamalarn neredeyse her alanda ön plana çıkmaktadır. Çevresel sürdürülebilirlik kaygılar gıda tüketim alışkanlıklarm da etkilemektedir. Sürdürülebilir tarım ve organik hareket de son zamanlarda hız kazanmıştır. Bu bağlamda bu çalışmanın amacı geçmiş çalı̧̧malar ve tüketici görüşlerini inceleyerek organik gıdaları çevresel sürdürülebilirlik çerçevesinde değerlendirmektir. Çalı̧̧ada organik gıdanın tüketici bakış açısıyla çevresel sürdürülebilirlik bakımından incelenmesi hedeflenmektedir. $\mathrm{Bu}$ amaç doğrultusunda veri elde etmede derinlemesine mülakat tekniği kullanılmıştır. Çalışmanın sonuçlan sürdürülebilir tüketim ile organik gıda satın alma niyetinin birbiriyle ilgili görüldü̈̆̈̈̈nü göstermektedir. Organik gıda satın alma niyetinde çevresel duyarlılk ve çevresel bilginin pozitif rolleri, şüpheciliğin ise negatif rolü bulunduğu önerilmiştir.

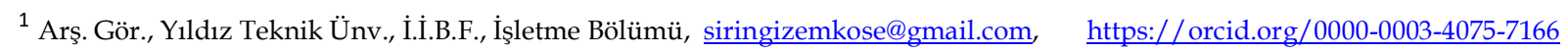




\section{INTRODUCTION}

The world passes through hard times in terms of sustainability. The increase of environmental sensitivity and knowledge also raises the importance that customers and governments attach to sustainability issues. Consumers change their spending habits and choices; governments revise their policies in line with sustainability purposes. Academic research on sustainability is also gaining ground.

The three elements of sustainable development are ecology, economy, and society. Ecological sustainability means that the development process is in harmony with ecology; economic sustainability requires economically feasible development, while social sustainability encompasses socially acceptable development and calls for global equity (Helms, 2004). Focusing on sustainability can help companies to follow global developments on essential issues such as climate change, insufficient water, and food sources (Baldwin \& Wilberforce, 2009). Organic production has also increased its importance in recent years due to its superiority on economic, social, and environmental roles when compared to conventional agriculture which is criticized because of its adverse effects on the environment and health (Toma et al., 2017).

Turkish customers also have an environmental concern which leads them to purchase green products (Tanrikulu, 2015; Uysal \& Esen, 2017). Conscious consumers are increasingly concerned about pesticides that are used in food production. Therefore, they increasingly prefer organic foods that do not harm the environment and health (Onurlubaş et al., 2020). Çelik's (2013) study suggests that being produced in an environmentally sensitive way is one of the primary reasons for purchasing organic food for Turkish consumers. There is a relationship between environmental consciousness and organic eating (Pektaş \& Gürce, 2018). Acceptable agricultural practices that started in 2007 in 18 cities in Turkey have significantly improved as a result of the supports. In order to make this improvement continue, it is essential to increase the demand for these products (Eryılmaz \& Kılıç, 2018). Therefore, it is a vital issue to understand customers' perspectives. 


\section{CONCEPTUAL FRAMEWORK}

\subsection{Sustainable Agriculture \& Organic Farming}

Industrialized agriculture is "the agriculture produced by using additives such as pesticides, fertilizers, genetically modified ingredients" (Garcia-Ramon, 2019). Agricultural products are vitally important since they are directly consumed or used as a raw material for further production. Turkey has very high agricultural potential. Agriculture has been a significant way of earning livelihood for the Turkish community, and it also has a prominent place in the Turkish economy (Taş, 2011). In Turkey, four significant agricultural changes have affected nature since the 1950s. These changes are; expanding of agricultural areas, increasing usage of chemicals, the increase of irrigation, and the annihilation of traditional agriculture (Kutlu \& Akdamar, 2008). To protect ecological balance, achieve sustainability in agriculture, and provide quality products in Turkey; it is aimed to increase organic production and consumption by regulating and developing organic agricultural production and marketing. In line with those targets, the Turkish Ministry of Agriculture and Forestry has prepared Organic Agriculture Law with the contributions of stakeholders in 2004. With those regulations, significant improvements have been achieved in organic agriculture (Çakır et al., 2015).

As the side effects of industrial farming are recognized, sustainable agricultural practices gained attention both academically and practically. Although sustainable agriculture and organic farming are the two prominent areas regarding this issue, there is no specific agreement on whether sustainable agriculture and organic farming refer to the same concept. Although there is no clear cut between organic farming and sustainable agriculture, these terms can be addressed as related but different concepts. Organic farming is a regulated and controlled way of production, while sustainable agriculture is based on environmental protection, economic growth, and social fairness; which are the core elements of the sustainability principle (Goldberger, 2011).

Defining sustainable agriculture is ambiguous since sustainability practices are hard to determine and measure. There is also uncertainty on the necessary time of being sustainable to be accepted as sustainable for agricultural land (Rigby \& Câceres, 2001). Biodiversity is as essential as water and soil management for sustainable 
agriculture. Sustainable agricultural systems are promoted because of their potential to preserve wildlife and as well as decreasing environmental damage (Pacini et al., 2003).

Sustainable agriculture is an agricultural structure that protects natural resources in the long term but also uses agricultural technologies that do not harm the environment. Using synthetic inputs, and techniques that have negative consequences also had adverse effects for Turkish agriculture. Sustainable farming techniques include protecting water and soil resources, integrated pesticide management. Organic farming techniques play a crucial role in sustainable farming by meeting quality, health and environmental standards (Turhan, 2005).

Organic farming integrates agroecological approaches with productivity since it is a deterrent and system-based approach (Niggli, 2015). Organic standards that are guided by organic principles give a signal of being organic to consumers (Smith, 2006). There are several reasons for choosing organic farming instead of conventional. Both internal and external factors play roles in the decision process. As Darnhofer et al. (2005) and Lotter (2003) point out, technical issues, as well as personal values, affect the choice of converting to organic farming. Usage of chemical fertilizers and pesticides, the annihilation of wildlife, harming human health, and the environment made current agricultural methods questionable. As a result of the concern towards modern agricultural methods, organic farming has increased its prominence (Rigby et al., 2001). According to Mondelaers et al. (2009), organic farming has a beneficial effect on both agro-biodiversity and biodiversity comparing with conventional farming. Since organic farming methods form on ecological welfare, its decreasing negative environmental impact of the food industry is another purpose of it. Together with protecting the environment goal, organic farming also keeps the soil and contributes to saving non-renewable resources (Gomiero et al., 2011).

\subsection{Organic Food as Sustainable Choice}

Creating quality living conditions for people has created a novel social movement, and new products emerged as a consequence. However, nowadays, consumers are more aware of the risks of using non-ecological products. Therefore, consumers are more cautious about what they buy and the effects of their purchases 
on environmental sustainability. Changing consumer preferences lead to altering the functioning of the industries (Gierszewska \& Seretny, 2019). Consumers engage actively in the sustainable economic development process, and they are aware of global sustainability issues. Worldwide consumers request more information about the products they consume, such as their origin and ingredients (Seretny \& Seretny, 2012). Paavola (2001) defined sustainable consumption as consumer behaviour that has less environmental effects compared to other consumption styles. Sustainable consumption has become a fundamental part of policies both locally and internationally. Customers play an essential role in converting to sustainable consumption with their actions, such as purchasing recycled and ethically produced goods (Seyfang, 2006). Dogan et al. (2015) showed that sustainable consumption dimensions are environmental sensitivity, redundant consumption, savings, and reusability in their scale development study. On the other hand, environmental sustainability is defined as sustaining natural resources and protecting biological diversity, human health, air, water and soil quality, the life of animals and plants (Eryılmaz et al., 2019).

The attitude-behaviour gap is often discussed in the sustainability literature; consumers may have positive feelings towards sustainable consumption, but the attitude does not necessarily turn into actual purchase. The same concept applied to organic food as well as other green products. In their experiment on organic yoghurt, Laureati et al. (2013) revealed that the intention to behave sustainably is usually low, although sustainable products are considered safe, healthy, and of high quality.

Information about sustainability has been given on food products for a while to brief consumers and promote sustainable consumption because food consumption is believed to affect the environment (Grunert et al., 2014). Sustainable consumption has started to be an essential part of governmental policies, and organic food is accepted as a useful tool for transformation to a sustainable system (Seyfang, 2007). The relationship between sustainable consumption and organic food purchase intention still needs to be investigated.

Conscious consumers are more aware of the adverse effects of consumption and think more deeply about the consequences of their consumption on society (Iwata, 
2006). Various researchers proved the relationship between environment-related variables such as environmental consciousness, environmental concern (Grunert \& Juhl, 1995; Gill et al., 2000), and organic food purchase intention. There are also contradicting findings in the literature, depending on the sample and context. Ueasangkomsatea \& Santiteerakul (2016) proved that local origin, animal welfare, and the environmental attribute of organic food is significantly related to organic food purchase intention. Health and food safety are also related variables, but their effect is less than the variables about sustainability. Asif et al. (2018) found that environmental concern does not affect the intention to purchase organic food. However, Annunziata \& Vecchio's (2016) research demonstrates that health and quality features of organic foods are more important than environment and rural development opportunities while making a purchasing decision. Yadav \& Pathak (2016) also found that environmental concerns did not affect organic food purchase intention. Those contradicting findings point out that this issue needs further research. Still, organic food is evaluated in the framework of sustainability practices (Niggli, 2015), and preferring organic over conventional food products is considered a way to increase the level of sustainability of food consumption (Thøgersen, 2010; Stern, 2000).

Furthermore, Thøgersen (2010) and Minton et al. $(2012,2015)$ claim that organic food consumption is a way to measure sustainable behaviours. Therefore, it is expected that consumers who have a higher tendency towards sustainable consumption tend to buy organic foods. Ayan et al. (2017) also found that consumers think organic food is healthier than conventional alternatives. The study of Oraman \& Unakitan (2010) points out that concern for human health and safety are significant motivators of choosing organic food. Y1lmaz \& Ilter (2017) suggest that health consciousness, perception, consumer values, price perception, environmental concerns predict purchase intention of organic foods. Besides, İlyasoğlu et al. (2010) added that consumption of organic food depends on perceiving the food as healthy, environment friendly, and high in nutrition. Kvatchadze \& Akınc1 (2018) stated that attitude is a significant determinant of purchase intention; while health consciousness, environmental consciousness, and organic food knowledge affect attitude towards organic foods. Örs (2019) also found that the price sensitivity of organic consumers is 
low; the consumers of organic food are motivated by health consciousness and social responsibility.

\section{METHODOLOGY}

The purpose of this study is to evaluate organic food within the framework of sustainability. This study chose a deep interview method as a qualitative data collection method, and ten in-depth interviews were conducted. Participants are aged between $25-45$ years old. They all have a university degree. Five women and five men were interviewed. The in-depth interview is a method that comprises all dimensions of the investigated subject, mostly includes open-ended questions, and enables getting detailed answers (Tekin, 2006). The method is defined as interviewing people who are relevant to the research subject with a specific purpose (Greasley \& Ashworth, 2007). The main objective of in-depth interviews is revealing and exploring feelings, perspectives and opinions of participants (Baş \& Akturan, 2008). Therefore, a deep interview method is suitable for researches that investigate reasons for behaviour and ideas on a specific topic. The in-depth interview is suggested as a method that provides deep data and knowledge (Türnüklü, 2000).

The interviews started with participants' views on sustainability and organic food and continued with their specific ideas on these issues. Ten people who are knowledgeable about sustainability practices, sustainable consumption, and organic foods are interviewed with the objective of purposive sampling. The reason behind this selection is when interviewers know these issues, they can conveniently express themselves and do not have conflict about the concepts. Since the interviews were conducted before January 2020, the study did not require ethical approval. The interviews were then transferred to the NVivo program and categorized. According to the interviews, hypotheses are proposed, and at the end of the study, a conceptual model is proposed.

\section{FINDINGS}

\subsection{Sustainable Consumption and Organic Food Relationship}

The majority of the participants indicated that there is a connection between sustainability and organic foods, so organic food can be considered as a sustainable 
consumption behaviour. According to participants, the fundamental reason behind this agreement is the fact that organic food production processes do not include using chemicals and pesticides which harms the soil and the environment.

"Of course, sustainability and organic foods are related - the most important supporting example as fallowing. Fallow is crucial for soil and the quality of agriculture. However, if we always sow the soil for financial purposes, add chemicals, what we get is unhealthful, the defective product that also inhibits soil sustainability."

"The soil normally does not need chemicals to adapt to nature and to be fertile. If we destroy the sustainability of the soil with human interventions, we kill agriculture. This leads us to look for artificial spaces that act to the soil. Why do we need that? We already have a working mechanism in nature, we should sustainably protect that, and organic production is a method to achieve that."

"Chemicals and pesticides used in agriculture directly affect consumers' health and nature. Organic agriculture, on the other hand, stays away from those and therefore does not yield destructive results. Therefore, sustainability and organic food production are supporting concepts for me."

"Organic food is sustainable because it does not harm soil and water, which are necessary for the continuation of human life and health."

"With the help of the rigorous methods used in organic agriculture production and consumption process, problems such as wasting and destroying natural resources decrease. As a result, we will have an environmental heritage that we can hand down the next generations. Those results are more attainable with organic agriculture when compared to conventional agriculture and directly related to sustainability."

As a result, it was proposed that:

P1: Sustainable consumption behaviour is a positive predictor of organic food consumption behaviour.

\subsection{Role of Scepticism}

Participants remarked that scepticism comes to the forefront in the connection between sustainability and organic foods. Most of the participants have a high level of scepticism toward organic food, especially when it is commercialized. They try to buy from trusted sellers to decrease the risk to be deceived. Golob et al. (2018) also found 
that scepticism negatively affects organic food purchase intention.

"Organic food is sustainable as long as it is not extensively commercialized. We should distinguish real organics from swindlers. Sellers sometimes claim that the food is organic, but use pesticides in farms. These sellers destroy not only the environment but also the taste of vegetables and fruits."

"If I believe the food is good for soil and environment and it is from a trustable source, I buy organic. However, some sellers only focus on the economic part of sustainability. I interrogate the seller to be sure."

"I think organic food is good for the environment only if it is organic. If I believe that the food is organic, my approach would be more positive, and there is a high chance that I would buy the food."

"All humanity cannot be fed with organic foods; therefore, real organic food is a niche. I underline the word real because consumers are often deceived by selling non-organic foods as organic."

Therefore, it was proposed that:

P2: Scepticism is a negative predictor of organic food purchase intention

P3: Scepticism moderates the relationship between sustainable consumption behaviour and organic food purchase intention.

\subsection{Role of Environmental Sensitivity}

Participants' views point out that environmental sensitivity is significant in the connection between sustainability and organic food. All participants that consider sustainability and organic foods in a holistic way specified that they have a high level of environmental sensitivity. Past literature also supports that environmental factors affect organic food purchase intention (De Magistris, \& Gracia, 2008; Janssen, 2018; Golob et al., 2018).

"I am seriously diligent when it comes to nutrition. I regularly buy organic food from a trusted farm. It is good for our health; I accept but also think we all should be environmentally sensitive. I try to warn people around me about environmental issues. The world is ours."

"If we do not care about the environment, there will be consequences. All environmental problems are tied to each other; therefore, everybody should be sensitive. We pollute the seas, and we eat fish from those polluted seas. We poison the soil, and then we eat vegetables from 
that soil. I am not happy with this situation and planning to change my eating habits."

"I do care about the environment, and I reflect this in my actions, for example, I want to buy an electric car for individual contribution to low carbon emission. I am conscious that organic food is beneficial for the environment as well as my health. Therefore, I try to buy organic food as much as possible."

Moreover, it was proposed that:

P4: Environmental sensitivity is a positive predictor of organic food purchase intention

P5: Environmental sensitivity moderates the relationship between sustainable consumption behaviour and organic food purchase intention.

\subsection{Role of Environmental Knowledge}

As Grunert (2011) underlined, just using eco-labels will not generate significant results unless consumers are knowledgeable about the meaning of eco-labelling and trust the credibility of these labels. Zepeda \& Deal's study (2009) also supports that the fact "attitudes are shaped by knowledge" is especially true for organic food consumers since they are passionate about gaining information and they are always craving for information. Furthermore, Demirtaş (2019) found that organic food knowledge is a predictor of organic food demand.

The results of the study showed that consumers' advanced environmental knowledge has a positive influence on the inclusion of organic food in the sustainable consumption process. This influence was expressed with the following statements:

"I do not use chemicals for my garden, even for cleaning purposes. I am susceptible to the effect of chemicals on the environment, so I did a deep research about chemicals in farming. Organic is advantageous in terms of time, money, and sustainability."

"Organic food can be approached as sustainable consumption when it appeals to people who know something about farming, and who have enough commitment to the environment."

"People who are sensitive about the environment should know what damages and what serves the environment to change their decisions. In the case of organic foods, I know that the soil needs to rest to refresh its minerals; and this also brings sustainability."

Thus, it was proposed that: 
P6: Environmental knowledge is a positive predictor of organic food purchase intention

P7: Environmental knowledge moderates the relationship between sustainable consumption behaviour and organic food purchase intention.

Figure 1 demonstrates the proposed relationships between constructs. The figure is based on the proposals that were developed from the interviews.

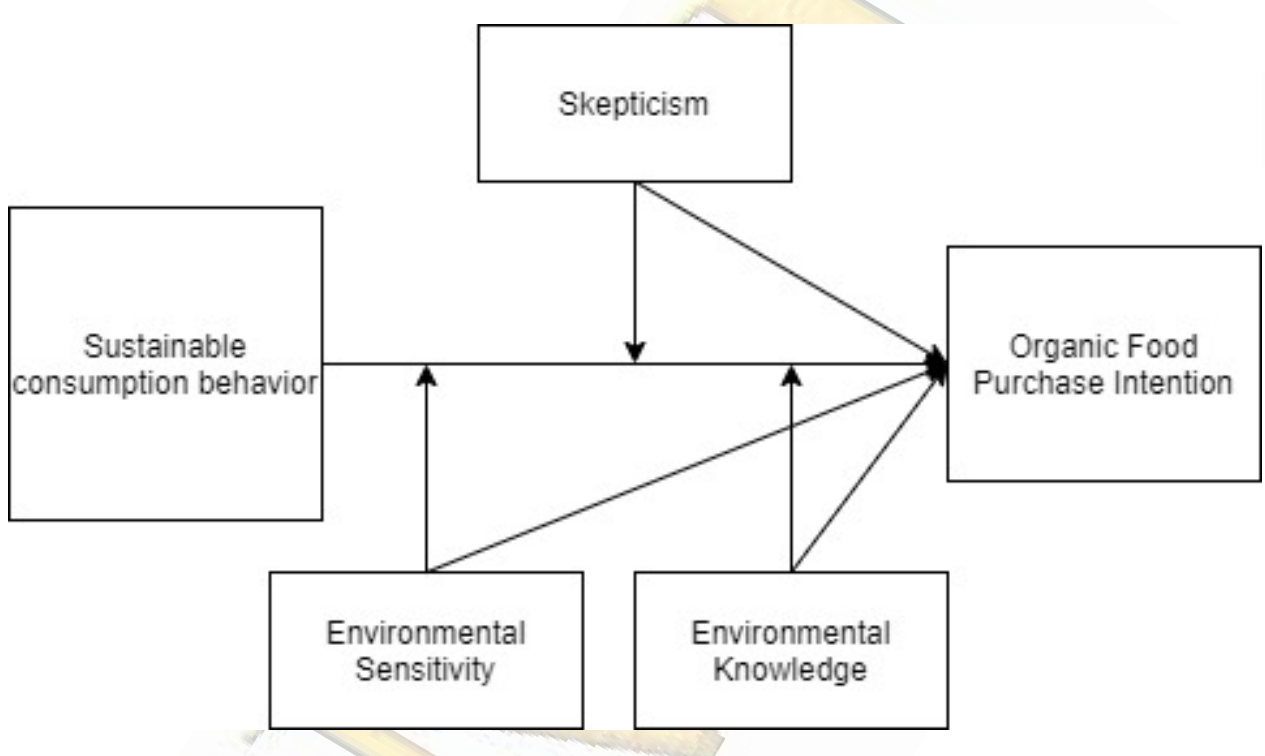

Figure 1. Proposed Model

Source: Developed by the author.

\section{CONCLUSION}

Sustainable consumption concept is related to decreasing or modifying consumption and puts forward recycling, using eco-products (Dogan et al., 2015). On the other hand, food and food production are fundamental to existence. However, the methods used to maintain this existence have consequences for the environment and natural sources (Bryla, 2015). From that point of view, this study intended to evaluate organic food in the framework of sustainability and sustainable consumption. The findings of the study clarify that most of the participants think that organic food consumption is a part of consumer-level sustainability practice. They support the connection between sustainability and organic food purchase. However, the participants added some factors that ease or obstruct the connection. 
The first easing element is environmental knowledge. As supported by this study, having inadequate information prevents consumers from applying sustainable practices, even though they have good intentions. As consumers' knowledge of the contribution of organic farming on sustainability, it is expected that their interest in organic farming, sustainable agriculture, and as a matter of course, organic food. Nowadays, it is blindingly apparent that consumers' interest in environmental issues is increasing. The second easing factor is environmental sensitivity. The more environmentally sensitive consumers get, the more likely they purchase organic foods under the effect of sustainability concerns.

The finding of the study points to the negative role of scepticism when it comes to sustainability and organic food. Consumers face numerous alternatives, and they are exposed to various messages. Turning good intentions regarding sustainability to actual sales depends on persuading consumers. Therefore, other essential issues are the credibility of eco-labelling, which points out that organic food is sustainable, and communicating the sustainability side of organic food consumption. To overcome the credence barriers and for effective communication, all stakeholders should work in an integrated way. While consumers' preference affects sales and therefore, the production of organic food products, they are restrained by macro factors, so government policies are also vital in encouraging sustainable techniques.

In conclusion, this paper highlights the importance of organic food and therefore organic agriculture for the sustainability of food and sustainability in general. From the consumer side, knowledge and credibility are essential for forming positive attitudes, while a holistic approach where all participants of the process contribute to sustainable development could be beneficial on the supply side. Although organic food purchasing may result from sustainability motivation, the fact that organic food consumers are also strongly motivated by health concerns should also be kept in mind in future studies. Another suggestion could be segmenting consumers to reach them better by taking into consideration their traits. Since this study is qualitative, it does not have a generalizability purpose, and the sample is narrow, future studies can research the proposed model on other consumer groups. 


\section{REFERENCES}

Annunziata, A., \& Vecchio, R. (2016). Organic farming and sustainability in food choices: An analysis of consumer preference in Southern Italy. Agriculture and agricultural science procedia, 8, 193-200.

Asif, M., Xuhui, W., Nasiri, A., \& Ayyub, S. (2018). Determinant factors influencing organic food purchase intention and the moderating role of awareness: A comparative analysis. Food Quality and Preference, 63, 144-150.

Ayan, A. K., Boz, İ., Kaynakci, C., \& Aytac, S. (2017). Consumers' perceptions of organic food items: A case study of Sisli and Kartal organic bazaars of Istanbul. International Journal of Agriculture and Environmental Research. 2017b, 3(5), 3635-43.

Baldwin, C. \& Wilberforce, N.T. (2009). Sustainability Principles and Sustainable Innovation for Food Products. Cheryl Baldwin (ed.) Sustainability in the Food Industry. Iowa: Wiley-Blackwell.

Baş, T., \& Akturan, U. (2008). Nitel araştırma yöntemleri: Nvivo 7.0 ile nitel veri analizi. Seçkin Yayincilık.

Bryła, P. (2015). The development of organic food market as an element of sustainable development concept implementation. Problemy Ekorozwoju-Problems of Sustainable Development, 10(1), 79-88.

Çakır, A., Ergun, M., Özbay, N. \& Osmanoğlu, A. (2015). Organik Güven. Doğu Karadeniz II. Organik Tarım Kongresi, Rize.

Çelik, S. (2013). Kimler, neden organik gida satın alıyor? Bir alan araştırması. Selçuk Üniversitesi Sosyal Bilimler Enstitüsü Dergisi, (30), 93-108.

Darnhofer, I., Schneeberger, W., \& Freyer, B. (2005). Converting or not converting to organic farming in Austria: Farmer types and their rationale. Agriculture and human values, 22(1), 39-52.

De Magistris, T., \& Gracia, A. (2008). The decision to buy organic food products in Southern Italy. British food journal.

Demirtas, B. (2019). Assessment of the impacts of the consumers' awareness of organic food on consumption behavior. Food Science and Technology, 39(4), 881-888.

Doğan, O., Bulut, Z. A., \& Çımrın, F. K. (2015). Bireylerin sürdürülebilir tüketim davranışlarının ölçülmesine yönelik bir ölçek geliştirme çalışması. Atatürk Üniversitesi İktisadi ve İdari Bilimler Dergisi, 29(4), 659-678.

Eryılmaz, G. A., \& Kılıç, O. (2018). Türkiye'de sürdürülebilir tarım ve iyi tarım uygulamaları. Tarım ve Doğa Dergisi, 21(4), 624.

Eryılmaz, G. A., Kılıç, O., \& Boz, İ. (2019). Türkiye'de organik tarım ve iyi tarım uygulamalarının ekonomik, sosyal ve çevresel sürdürülebilirlik açısından değerlendirilmesi. Yüzüncü Yıl Üniversitesi Tarım Bilimleri Dergisi, 29(2), 352-361.

Garcia-Ramon, L. (2019). “Got Water?” The Effects of Globalized Agribusiness on Consumers' Access to Water Sources. Markets, Globalization \& Development Review, 4(1).

Gierszewska, G., \& Seretny, M. (2019). Sustainable Behavior-The Need of Change in Consumer and Business Attitudes and Behavior. Foundations of Management, 11(1), 197-208. 
Gil, J. M., Gracia, A., \& Sanchez, M. (2000). Market segmentation and willingness to pay for organic products in Spain. The International Food and Agribusiness Management Review, 3(2), 207-226.

Goldberger, J. R. (2011). Conventionalization, civic engagement, and the sustainability of organic agriculture. Journal of Rural Studies, 27(3), 288-296.

Golob, U., Koklic, M. K., Podnar, K., \& Zabkar, V. (2018). The role of environmentally conscious purchase behaviour and green scepticism in organic food consumption. British Food Journal.

Gomiero, T., Pimentel, D., \& Paoletti, M. G. (2011). Environmental impact of different agricultural management practices: conventional vs. organic agriculture. Critical reviews in plant sciences, 30(1-2), 95-124.

Greasley, K., \& Ashworth, P. (2007). The phenomenology of 'approach to studying': The university student's studies within the lifeworld. British Educational Research Journal, 33(6), 819-843.

Grunert, S. C., \& Juhl, H. J. (1995). Values, environmental attitudes, and buying of organic foods. Journal of economic psychology, 16(1), 39-62.

Grunert, K. G. (2011). Sustainability in the food sector: A consumer behaviour perspective. International Journal on Food System Dynamics, 2(3), 207-218.

Grunert, K. G., Hieke, S., \& Wills, J. (2014). Sustainability labels on food products: Consumer motivation, understanding and use. Food Policy, 44, 177-189.

Helms, M. (2004). Food sustainability, food security and the environment. British Food Journal, 106(5), 380-387.

Iwata, O. (2006). An evaluation of consumerism and lifestyle as correlates of a voluntary simplicity lifestyle. Social Behavior and Personality: an international journal, 34(5), 557-568.

İlyasoğlu, H., Temel, S., \& Özçelík, B. (2010). Consumer perceptions of organic foods in Turkey. Journal of Food, Agriculture \& Environment, 8(3/4 part 1), 279-281.

Janssen, M. (2018). Determinants of organic food purchases: Evidence from household panel data. Food Quality and Preference, 68, 19-28.

Kutlu, Ü.B. \& Akdamar, M. (2008). Türkiye' de Tarım ve Doğa. Türkiye için Doğa Dostu Tarım Kitapçığı. Redman, M. \& Hemmami. M. (Ed.) Ankara Türkiye için Doğa Dostu Tarım Programı Geliştirilmesi" Projesi.

Kvatchadze, S., \& Akıncı, S. (2018). Sağlık Bilinci, Çevre Bilinci ve Organik Gıda Bilgisinin Satın Alma Niyetine Organik Gıdalara Yönelik Tutum Aracılı̆̆ıla Etkisi. Akdeniz Üniversitesi İktisadi ve İdari Bilimler Fakültesi Dergisi, 18(37), 158-183.

Laureati, M., Jabes, D., Russo, V., \& Pagliarini, E. (2013). Sustainability and organic production: how information influences consumer's expectation and preference for yogurt. Food quality and preference, $30(1), 1-8$.

Lotter, D. W. (2003). Organic agriculture. Journal of sustainable agriculture, 21(4), 59-128.

Minton, E., Lee, C., Orth, U., Kim, C. H., \& Kahle, L. (2012). Sustainable marketing and social media: A cross-country analysis of motives for sustainable behaviors. Journal of Advertising, 41(4), 69-84. 
Minton, E. A., Kahle, L. R., \& Kim, C. H. (2015). Religion and motives for sustainable behaviors: A crosscultural comparison and contrast. Journal of Business Research, 68(9), 1937-1944.

Mondelaers, K., Aertsens, J., \& Van Huylenbroeck, G. (2009). A meta-analysis of the differences in environmental impacts between organic and conventional farming. British food journal, 111(10), 10981119 .

Niggli, U. (2015). Sustainability of organic food production: challenges and innovations. Proceedings of the Nutrition Society, 74(1), 83-88.

Onurlubaş, E., Gümüş, N., \& Karaca, Ş. (2020). Tüketicilerin Organik Yumurta Satın Alma Niyetini Etkileyen Faktörlerin Yapısal Eşitlik Modeli İle İncelenmesi. Sosyal Bilimler Arastirmalari Dergisi, 10(1).

Oraman, Y., \& Unakitan, G. (2010). Analysis of factors influencing organic fruit and vegetable purchasing in Istanbul, Turkey. Ecology of food and nutrition, 49(6), 452-466.

Örs, M. (2019). Organik Ürün Satınalma Niyetine Etki Eden Faktörlerde Fiyat Algısının Düzenleyici Rolü. Business and Management Studies: An International Journal, 7(2), 891-925.

Paavola, J. (2001). Towards sustainable consumption: economics and ethical concerns for the environment in consumer choices. Review of social economy, 59(2), 227-248.

Pacini, C., Wossink, A., Giesen, G., Vazzana, C., \& Huirne, R. (2003). Evaluation of sustainability of organic, integrated and conventional farming systems: a farm and field-scale analysis. Agriculture, Ecosystems \& Environment, 95(1), 273-288.

Pektaş, G. Ö. E., \& Gürce, M. Y. Tüketicilerin Diyete Yatkınlıkları, Organik Beslenme ve Çevreye Duyarlı Davranışları Arasındaki İlişki Üzerine Bir Araştırma. Gaziantep University Journal of Social Sciences, 17(4), 1507-1515.

Rigby, D., \& Cáceres, D. (2001). Organic farming and the sustainability of agricultural systems. Agricultural Systems, 68(1), 21-40.

Rigby, D., Woodhouse, P., Young, T., \& Burton, M. (2001). Constructing a farm level indicator of sustainable agricultural practice. Ecological economics, 39(3), 463-478.

Seretny, M., \& Seretny, A. (2012). Sustainable marketing-a new era in the responsible marketing development. Foundations of management, 4(2), 63-76.

Seyfang, G. (2006). Ecological citizenship and sustainable consumption: Examining local organic food networks. Journal of rural studies, 22(4), 383-395.

Seyfang, G. (2007). Growing sustainable consumption communities: the case of local organic food networks. International Journal of Sociology and Social Policy, 27(3/4), 120-134.

Smith, A. (2006). Green niches in sustainable development: the case of organic food in the United Kingdom. Environment and Planning C: Government and Policy, 24(3), 439-458.

Stern, P. C. (2000). New environmental theories: toward a coherent theory of environmentally significant behavior. Journal of social issues, 56(3), 407-424. 
Tanrıkulu, C. (2015). Çevresel kaygı, algılanan tüketici etkinliği ve kollektivizmin, tüketicilerin yeşil satın alma davranışlarındaki rolü üzerine bir inceleme. Ataturk University Journal of Economics \& Administrative Sciences, 29(1), 121-136.

Taş, B. (2011). Türkiye'de tarımsal işletmelerin coğrafi dağılışı (2007). Doğu Coğrafya Dergisi, 15(23), $31-46$.

Tekin, H. H (2006). Nitel Araştirma Yönteminin Bir Veri Toplama Tekniği Olarak Derinlemesine Görüşme. İstanbul Üniversitesi Sosyoloji Dergisi, 3(13), 101-116.

Thøgersen, J. (2010). Country differences in sustainable consumption: The case of organic food. Journal of Macromarketing, 30(2), 171-185.

Toma, M. A., Bobe, M., \& Procopie, R. (2017, May). Organic vs conventional food. A sustainable consumption approach. In Pamfilie, R., Dinu, V., Tăchiciu, L., Pleșea, D. and Vasiliu, C., BASIQ International Conference: New Trends in Sustainable Business and Consumption-2017.. Graz, Austria (Vol. 31).

Turhan, Ş. (2005). Tarimda sürdürülebilirlik ve organik tarim. Tarım Ekonomisi Dergisi, 11(1 ve 2), 1324.

Türnüklü, A. (2000). Eğitimbilim araştırmalarında etkin olarak kullanılabilecek nitel biraraştırma tekniği: Görüşme. Kuram ve Uygulamada Egitim Yönetimi Dergisi, 6(4), 543-559.

Ueasangkomsate, P., \& Santiteerakul, S. (2016). A study of consumers' attitudes and intention to buy organic foods for sustainability. Procedia Environmental Sciences, 34, 423-430.

Uysal, N. B. \& Esen, S.K. (2017). Yeşil satınalma davranışının incelenmesi: çevresel kaygının, algılanan tüketici etkinliğinin ve demografik faktörlerin etkileri. Dokuz Eylul Universitesi Sosyal Bilimer Enstitusu Dergisi, 19(2), 205.

Yadav, R., \& Pathak, G. S. (2016). Intention to purchase organic food among young consumers: Evidences from a developing nation. Appetite, 96, 122-128.

Yılmaz, B. S., \& Ilter, B. (2017). Motives underlying organic food consumption in Turkey: Impact of health, environment and consumer values on purchase intentions. Economics World, 5(4), 333-345.

Zepeda, L., \& Deal, D. (2009). Organic and local food consumer behaviour: Alphabet theory. International Journal of Consumer Studies, 33(6), 697-705. 